\title{
Polymorphism, Allelic and Genotypic Frequencies of $\kappa$-Casein and $\beta$-LG genes in Egyptian Buffaloes
}

\author{
Z. M. Al-Shawa ${ }^{1}$, M. F. El-Zarei ${ }^{1,2}$, A. A. Ghazy ${ }^{1}$, M. A. Ayoub ${ }^{1}$, S. M. Merdan ${ }^{1} \&$ S. A. Mokhtar ${ }^{1}$ \\ ${ }^{1}$ Department of Animal Production, Faculty of Agriculture, Suez Canal University, Ismailia, Egypt \\ ${ }^{2}$ Department of Animal Production and Breeding, College of Agriculture and Veterinary Medicine, Qassim \\ University, Buraydah, Saudi Arabia \\ Correspondence: M. F. El-Zarei, Department of Animal Production and Breeding, College of Agriculture and \\ Veterinary Medicine, Qassim University, Buraydah 51452, Saudi Arabia. Tel: 966-6380-0050 Ext. 2287. E-mail: \\ zray@qu.edu.sa
}

Received: January 28, 2020

Accepted: March 1, $2020 \quad$ Online Published: March 15, 2020

doi:10.5539/jas.v12n4p283

URL: https://doi.org/10.5539/jas.v12n4p283

\begin{abstract}
With a view to detecting the genotypes of both $\kappa-\mathrm{CN}$ and $\beta$-LG genes in native populations of Egyptian buffalo using PCR-RFLP technique, 80 randomly, individuals were selected from five geographical locations of some Egyptian provinces. Also, to estimate the population genetic parameters such as, allelic and genotypic frequencies, heterozygosity, and inbreeding coefficient $\left(\mathrm{F}_{\mathrm{IS}}\right)$ of these studied genes. For genotyping, $453 \mathrm{bp}$ PCR product of $\kappa-\mathrm{CN}$ was digested with $\mathrm{AcuI}$ and $\mathrm{HpyCH} 4 \mathrm{IV}$ (Isoschizomer for MaeII) restriction enzymes while the 247 bp PCR product of $\beta$-LG was digested with HaeIII restriction enzyme. PCR-RFLP results discovered polymorphism at the level of $\kappa-\mathrm{CN}$ gene in all studied Egyptian buffaloes with two distinct alleles "A" and "B". PCR-RFLP analysis for $\kappa-\mathrm{CN}$ gene using both restriction enzymes successfully detected that polymorphic status of the studied populations. We recommended using $A c u$ I enzyme which was more capable for differentiating between homozygous (17\%) and heterozygous (83\%) individuals than HpyCH4IV enzyme which defined only $4 \%$ of homozygous individuals and the remaining was heterozygous $(96 \%)$ individuals. Existence of heterozygosity excess in all studied populations referred to higher degree of genetic variability between individuals within these populations. On contrary, results of PCR-RFLP at the level of $\beta$-LG gene revealed a monomorphic pattern of Egyptian buffaloes and genotyped as "AA" animals which signified that PCR-RFLP assay with HaeIII enzyme for $\beta$-LG gene failed to discover any evidence of polymorphism in Egyptian buffalo under the circumstances of this study or all studied animals possess only one allele.
\end{abstract}

Keywords: $A c u$ I, HaeIII, heterozygosity, HpyCH4IV, PCR-RFLP

\section{Introduction}

Buffalo has an economic value as multi-purpose animal particularly, in developing countries and plays a significant role through its contribution in many agricultural aspects. Buffaloes are ubiquitous distributed animal; they are stationed mostly in Asia, Africa, Americas and some European countries. According to FAO (2019), the world population of buffalo in 2017 was estimated to be $200,967,747$ head, of which $97.4 \%$ are in Asia, $1.7 \%$ is in Africa, almost entirely in Egypt, $0.7 \%$ is in Americas, and $0.2 \%$ is in Europe. The largest number of buffaloes is found in India and Pakistan (113,329,671 and 37,700,000 head, respectively). Genus of Water or Asian buffaloes (Bubalus) are broadly classified into two main different subspecies, known as the River and Swamp types, based on their morphological, behavioral and geographical criteria (Cockrill, 1981; Groeneveld et al., 2010).

Water river buffalo (Bubalus bubalis) is one of the important livestock animals in many regions of the developing countries. In Egypt, river buffalo is variably distributed all over the Nile valley and Nile delta (Hassanein et al., 2013). In 2017, the total number of Egyptian buffalo is 3,375,727 head. Approximately, $31 \%$ of buffalo population is found in three governorates, i.e., El-Sharqia, El-Behaira, and El-Menoufia as reported by FAO (2019).

Buffaloes play a vital role in the agricultural economy sector of numerous countries, especially in Egypt. Also, Buffaloes distinguished by their high immunity, adaptation with harsh climates and they are known as better converter of poor-quality roughage into milk and meat, contributing about $44.26 \%$ and $36 \%$ of Egypt's milk and 
meat production, respectively (Borghese \& Mazzi, 2005; Patel et al., 2007; Perera, 2011; Hassanein et al., 2013; Riaz, 2013; Hamad et al., 2014; FAO, 2019).

The discovery of DNA-level polymorphism in 1980s and its subsequent use as molecular markers has renewed interest in the use of genetic markers in selection of breeding stocks (Naqvi, 2007). The concept of marker assisted selection (MAS) refers to utilizing the information of polymorphic loci as an aid to selection; onwards of the 1990s, breeders used gene marker technology in the form of MAS to eliminate deleterious gene alleles or to select favorable conditions based on some marker information (Eggen, 2012). Through MAS of dairy livestock, some genes are suggested as potential candidates associated with dairy performance traits. Among different candidates, genetic variants of caseins $\left(\mathrm{CN}_{\mathrm{s}}\right)$ and $\beta$-Lactoglobulin $(\beta$-LG) have been extensively studied, and reported as important factors associated with lactation performance, milk composition and cheese yield efficiency (Hussain \& Twayej, 2016).

As reported by Lara et al., 2002, many invistigators (Golijow et al., 1999; Kemenes et al., 1999), are focusing on detecting milk protein polymorphisms as a potential tool for genetic choice and genetic characterization of bovine breeds. Until now, several types of molecular markers have been utilized to evaluate DNA polymorphisms, e.g. restriction fragment length polymorphisms (RFLPs), which were the first DNA-based marker for constructing genetic linkage maps; and by combining this method with PCR (PCR-RFLP), genetic polymorphisms of most important genes had been detected. The progress of PCR-RFLP technique enabled fast analysis of the polymorphisms of virtually unlimited number of genes, including that coding kappa casein ( $\kappa-\mathrm{CN}$ ) and $\beta$-LG genes (Yang et al., 2013). Nowadays, genetic marker research applied to animal breeding and production is concentrated mainly on analyzing mutations located within candidate genes and their relation with economically substantial traits (Awad et al., 2016).

Genetic distance is a measure of the genetic divergence between species or between populations within a species (Nei, 2001) and measures the accumulated number of gene (alleles) differences per locus between the two populations. There are various molecular markers data that can be used for measuring genetic distance, such as restriction analysis data, (RAPD) data, and microsatellite DNA data (Nei, 1972; Nei \& Takezaki, 1983). This progression has been motivated, at least in part, by a search for loci with more variation. Loci with many alleles, such as microsatellite loci, have unprecedented ability to detect and describe genetic differences between populations (Kalinowski, 2005).

The present study aimed to detect genotypes of $\kappa-\mathrm{CN}$ and $\beta-\mathrm{LG}$ genes of Egyptian buffaloes and to estimate the population genetic parameters of these genes.

\section{Materials and Methods}

\subsection{Location}

This study was carried out at Biotechnology Laboratory of Animal Production and Fish Resources Department, Faculty of Agriculture, Suez Canal University; Ismailia, Egypt.

\subsection{Samples Collection and DNA Extraction}

Data were collected in agreements with ethical standards, and safety guide procedures. 80 randomly blood samples were collected from five geographical locations of some Egyptian provinces as mentioned in Table 1. Approximately $5 \mathrm{ml}$ of blood was drawn per animal, in "K $\mathrm{K}_{3}$-EDTA" (an anticoagulant) coated sterile vacutainers and immediately preserved in a well-insulated icebox containing ice cool pack until reaching to the laboratory then stored at $-20{ }^{\circ} \mathrm{C}$ to the time of DNA extraction. Genomic DNA was isolated from the whole blood using commercial purification kit, (Quick-gDNA ${ }^{\mathrm{TM}}$ MiniPrep). DNA concentration and purity was estimated using NanoDrop (Spectrophotometer ND-1000). DNA concentrations ranged from (20 to $30 \mathrm{ng} / \mu \mathrm{l}$ ), with a purity ratio from 1.7 to 1.9 which was considered as a high DNA purity.

Table 1. List of farms used in the present study

\begin{tabular}{ll}
\hline Location/Farm & Animals No./Farm \\
\hline Farm of Agriculture College, Cairo University (C.F.) & 20 \\
Kafr El-Sheikh Agricultural Research Station (K.S.) & 29 \\
Farm of Agriculture College of Shebeen El-Kom, Menoufia University (Sh.F.) & 10 \\
Ismailia Agricultural Research Station (I.S.) & 11 \\
Sids Research Station, Beni Suef Governorate (S.S.) & 10 \\
\hline
\end{tabular}




\subsection{PCR-RFLP Assay}

\subsubsection{PCR Amplification}

Hence, a high degree of nucleotide sequence conservation between cattle and river buffalo were recorded, the primers used in this study are basically of cattle origin (Othman et al., 2011). Many investigators designed the primers according to cattle gene sequence (Medrano \& Aguilar-Cordova, 1990a; Medrano \& Aguilar-Cordova, 1990b; Barroso et al., 1998; Miluchová et al., 2012) to be used in buffalo (Patel et al., 2007; Riaz et al., 2008; El Nahas et al., 2013; El Nahas \& Abou Mossallam, 2015). Primers sequences of studied genes used in this study are presented in Table 2. The target sequences of $\kappa-\mathrm{CN}$ and $\beta-\mathrm{LG}$ genes were amplified with Polymorphism chain reaction (PCR) as described by Barroso et al. (1998); Miluchová et al. (2012), using genomic DNA extracted from individual animals. PCR was carried out in a final reaction volume of $25 \mu 1$. PCR mixture placed in $0.2 \mathrm{ml}$ thin wall PCR tubes. PCR reaction consisted of $5 \mu \mathrm{l}$ of genomic DNA, $12.5 \mu \mathrm{l} 2 \mathrm{x}$ of MyTaq Red Mix Master mix, $0.5 \mu \mathrm{l}$ of each forward and reverse primers and $6.5 \mu \mathrm{l}$ DNase free water. The PCR program was as following, $94{ }^{\circ} \mathrm{C}$ for $5 \mathrm{~min}$., followed by 35 cycles of $94{ }^{\circ} \mathrm{C}$ for $1 \mathrm{~min}$., $60^{\circ} \mathrm{C}$ for $1 \mathrm{~min}$. and $72{ }^{\circ} \mathrm{C}$ for $2 \mathrm{~min}$. and final extension step at $72{ }^{\circ} \mathrm{C}$ for $10 \mathrm{~min}$. PCR product of $453 \mathrm{bp}$ and $247 \mathrm{bp}$ were yielded for $\kappa-\mathrm{CN}$ and $\beta$-LG genes, respectively. Checking of the quality of these PCR products was confirmed by loading $5 \mu$ of each PCR product on $3 \%$ agarose gel $(80 \mathrm{ml})$ after staining with $0.5 \mu \mathrm{l}$ of ethidium bromide $(10 \mathrm{mg} / \mathrm{ml})$ in $1 \mathrm{x}$ TAE as a running buffer at a voltage of $100 \mathrm{v}, 40 \mathrm{~mA}$ for two hours. The amplified product was visualized as a single compact fluorescent band of expected size under UV light and photographed using Nikon (D3400) digital camera and then comparing the resulted band size with 100 bp ladder DNA marker.

Table 2. Primers sequences for $\kappa-\mathrm{CN}$ and $\beta-\mathrm{LG}$ genes

\begin{tabular}{lll}
\hline Gene & Sequence of used primer & References \\
\hline \multirow{2}{*}{ א-CN } & F 5'-TGTGCTGAGTAGGTATCCTAGTTATGG-3' & Medrano and Aguilar-Cordova (1990a); Barroso et al. (1998); Riaz et al. (2008); \\
& R 5'-GCGTTGTCTTCTTTGATGTCTCCT-3' & El Nahas et al. (2013); El Nahas and Abou Mossallam (2015) \\
\multirow{2}{*}{$\begin{array}{l}\text { B-LG } \\
\text { F 5'-TGTGCTGGACACCGACTACAAAAAG-3' } \\
\text { R 5'-GCTCCCGGTATATGACCACCCTCT-3' }\end{array}$} & Medrano and Aguilar-Cordova (1990b); Patel et al. (2007); Miluchová et al., (2012) \\
\hline
\end{tabular}

\subsubsection{RFLP Analysis for PCR Products}

(1) Digestion by Restriction Enzymes

PCR products were subjected to digestion by restriction enzymes (New England Biolabs ${ }_{\text {inc }}{ }^{\circledR}$, USA) suitable for each gene. For genotyping, the $453 \mathrm{bp}$ PCR product of $\kappa-\mathrm{CN}$ was digested with both $A c u \mathrm{I}$ and HpyCH4IV (Isoschizomer for MaeII) restriction enzymes ( 80 and 78 PCR product samples for each enzyme, respectively) while the 247 bp PCR product of $\beta$-LG was digested with HaeIII restriction enzyme (80 PCR product samples) as given in Table 3 .

Table 3. Restriction enzymes used and their recognition sites

\begin{tabular}{|c|c|c|c|}
\hline Gene & Used Enzyme & Recognition site & Reference \\
\hline \multirow{2}{*}{$\kappa-\mathrm{CN}$} & $A c u \mathrm{I}$ & $\begin{array}{l}5^{\prime} \ldots \text { CTGAAG }(\mathrm{N})_{16}{ }^{\top} \ldots 3^{\prime} \\
3^{\prime} \ldots \text { GACTTC }(\mathrm{N})_{14 \Lambda} \ldots 5^{\prime}\end{array}$ & El Nahas et al. (2013) \\
\hline & НруСH4IV & $\begin{array}{l}5^{\prime} \ldots \mathrm{A} \mathrm{CGT}^{\prime} .3^{\prime} \\
3^{\prime} \ldots \mathrm{TGC}_{\mathbf{\Delta}} \mathrm{A} \ldots 5^{\prime}\end{array}$ & Riaz et al. (2008) \\
\hline$\beta-\mathrm{LG}$ & HaeIII & $\begin{array}{l}5^{\prime} \ldots \mathrm{GG}{ }^{\nabla} \mathrm{CC} \ldots 3^{\prime} \\
3^{\prime} \ldots \mathrm{CC}_{\Delta} \mathrm{GG} 5^{\prime}\end{array}$ & Riaz (2013) \\
\hline
\end{tabular}

After the end of incubation period, the reaction was ended by putting PCR tubes in crushed ice for minutes, and then stored at $-20{ }^{\circ} \mathrm{C}$ until running on agarose gel $3 \%$ for genotyping.

\section{(2) Agarose Gel Electrophoresis of Restricted Products}

Restricted products were examined by running $15 \mu \mathrm{l}$ of digested PCR product from each tube on $3 \%$ agarose gel $(80 \mathrm{ml})$ after staining with $0.5 \mu \mathrm{l}$ of ethidium bromide $(10 \mathrm{mg} / \mathrm{ml})$ in $1 \mathrm{x}$ TAE as a running buffer at a voltage 100 $\mathrm{v}, 40 \mathrm{~mA}$ for two hours. The restricted fragments sizes were determined by comparing with 50 and $100 \mathrm{bp}$ standard ladder DNA marker for $\beta-\mathrm{LG}$ and $\kappa-\mathrm{CN}$, respectively. 
(3) Determination of Genetic Variants

For detection of $\kappa-\mathrm{CN}$ and $\beta-\mathrm{LG}$ genotypes, resulted bands of restricted products were analyzed manually by comparing with the standard DNA ladder co-migrated in the same gel and define the corresponding genotype according to literature review data. Detected fragments sizes corresponding to different $\kappa-\mathrm{CN}$ and $\beta$-LG genotypes after digesting PCR products with different restriction enzymes are summarized in Table 4.

Table 4. Detected fragments size corresponding to different $\kappa-\mathrm{CN}$ and $\beta$-LG genotypes using PCR-RFLP technique

\begin{tabular}{|c|c|c|c|c|}
\hline Gene & Restriction Enzyme (RE) & Genotype & $\begin{array}{l}\text { Fragments size (bp) after } \\
\text { digestion PCR Product } \\
\text { with restriction enzyme }\end{array}$ & References \\
\hline \multirow{4}{*}{$\kappa-\mathrm{CN}$} & \multirow{2}{*}{ AcuI } & AA & $453 \mathrm{bp}$ (uncut product) & El Nahas et al. (2013); El Nahas and Abou Mossallam (2015) \\
\hline & & $\mathrm{AB}$ & 453,339 , and $114 \mathrm{bp}$ & \\
\hline & \multirow{2}{*}{ Hpych4IV } & $\mathrm{BB}$ & 254 and 199 bp & Riaz et al. (2008) \\
\hline & & $\mathrm{AB}$ & 453,254 and $199 \mathrm{bp}$ & \\
\hline$\beta-\mathrm{LG}$ & HaeIII & AA & 148 and $99 \mathrm{bp}$ & Patel et al. (2007) and Miluchová et al. (2012) \\
\hline
\end{tabular}

\subsection{Statistical Analysis}

Allelic frequencies, observed $\left(\mathrm{H}_{\mathrm{o}}\right)$ and expected $\left(\mathrm{H}_{\mathrm{e}}\right)$ heterozygosity, and inbreeding coefficient $\left(\mathrm{F}_{\text {IS }}\right)$ per locus and population were calculated using FSTAT for windows, version 2.9.3.2 (Goudet, 2002). Genotypic frequencies per locus and population were calculated manually with the formula given below:

Frequency of observed heterozygotes $=$ Heterozygote Number/Total Number of Individuals

The distance tree analysis of the detected alleles of all gene loci for studied populations was carried out. A rooted genetic dendrogram was constructed by Nei (1972). POPTREE2 program version 2.0 (Takezaki et al., 2010) was used to perform evolutionary analyses of allele frequency data.

\section{Results and Discussion}

3.1 Detection of Polymorphism and Genetic Variants of $\kappa-C N$ and $\beta-L G$ Genes Using "PCR-RFLP” Technique

\subsubsection{PCR Amplification}

A single compact band of $453 \mathrm{bp}$ and $247 \mathrm{bp}$ for $\kappa-\mathrm{CN}$ and $\beta-\mathrm{LG}$, respectively was observed under UV light as depicted in Figures 1 and 2.

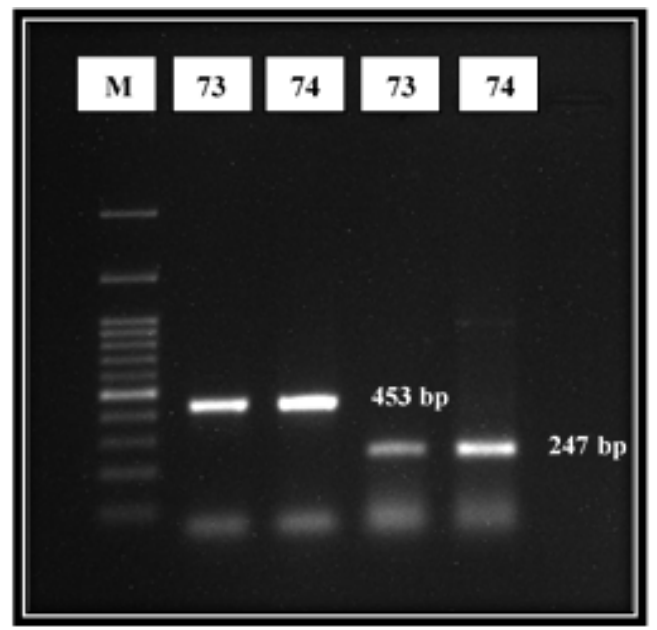

Figure 1. PCR product of $\kappa-\mathrm{CN}(453 \mathrm{bp})$ and $\beta$-LG (247 bp) genes. M Lane: $100 \mathrm{bp}$ DNA ladder. Animals codes 73 and 74. Run conditions: agarose gel $1 \%$ for $60 \mathrm{~min}$ at $100 \mathrm{v}$ and $40 \mathrm{~mA}$ 


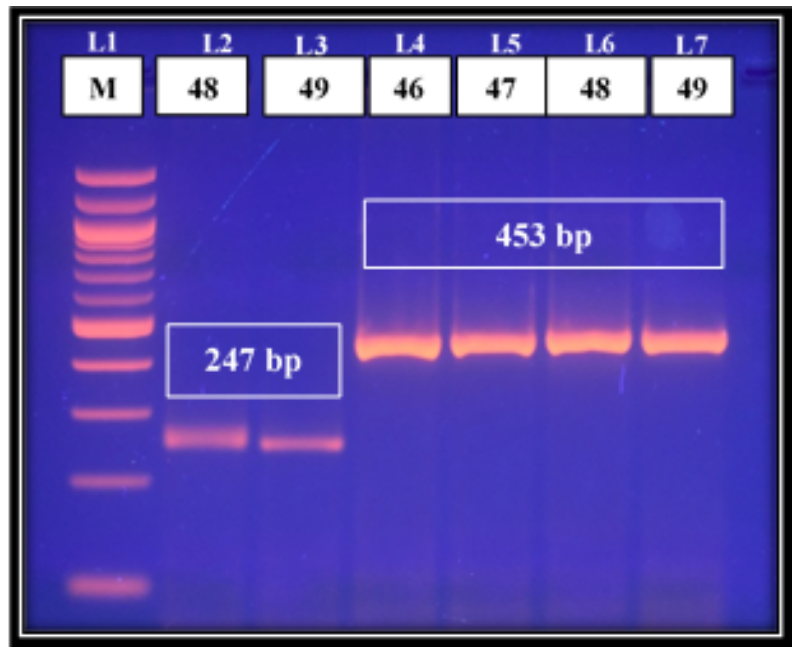

Figure 2. PCR product of $\kappa-\mathrm{CN}$ (lanes from 4 to 7 ) and $\beta$-LG (lanes 1 and 2) genes. M Lane: $100 \mathrm{bp} \mathrm{DNA} \mathrm{ladder.}$ Animals codes 46 to 49 . Run conditions: agarose gel $3 \%$ for $120 \mathrm{~min}$ at $100 \mathrm{v}$ and $40 \mathrm{~mA}$

\subsubsection{RFLP Analysis Results}

(1) RFLP analysis for PCR products of $\kappa-\mathrm{CN}$ gene (453 bp)

(a) Restriction Results Using AcuI Enzyme

After digestion of 453bp PCR products by $A c u$ I enzyme, restricted products were loaded on 3\%agarose gel for two hours at $100 \mathrm{v}$ and $40 \mathrm{~mA}$. Results of gel electrophoresis referred to existence of polymorphism at $\kappa-\mathrm{CN}$ gene with the following fragments patterns: The unrestricted band of $453 \mathrm{bp}$ for homozygotes "AA" and three bands of 453, 339, and $114 \mathrm{bp}$ for heterozygotes "AB" as observed in Figures 3 and 4.

(b) Restriction Results Using HpyCH4IV Enzyme

Digestion with HpyCH4IV enzyme yielded two patterns of restricted products (254 and $199 \mathrm{bp)}$ for homozygotes "BB" and (453, 254 and 199 bp) for heterozygotes "AB" as detected in Figure 4.

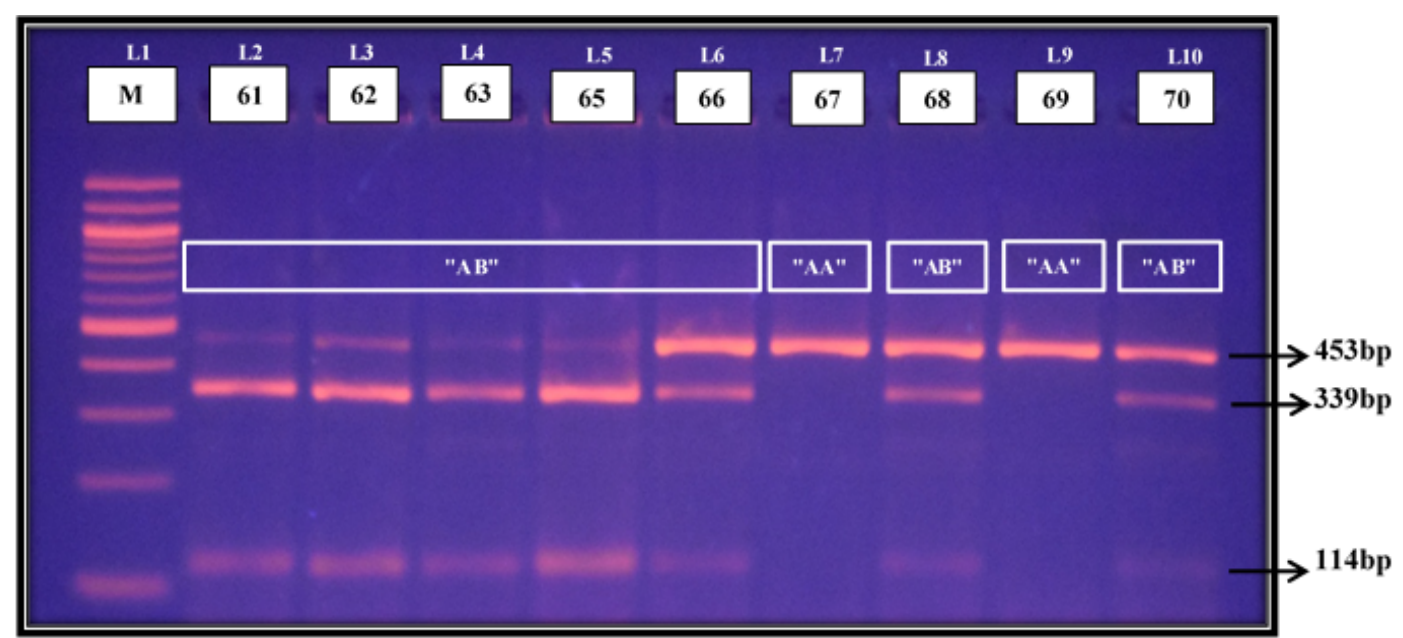

Figure 3. Gel electrophoresis for restricted fragments of $\kappa-\mathrm{CN}$ gene digested with $A c u \mathrm{I}$ enzyme. M Lane: $100 \mathrm{bp}$ DNA ladder. Animals codes 61 to 70. Lanes from L2 to L6, L8 and L10 represent AB genotype (453, 339, and $114 \mathrm{bp}$ ) while Lanes No. 7 and 9 represent AA genotype (453 bp; uncut product). Run conditions: agarose gel $3 \%$ for $120 \mathrm{~min}$ at $100 \mathrm{v}$ and $40 \mathrm{~mA}$ 


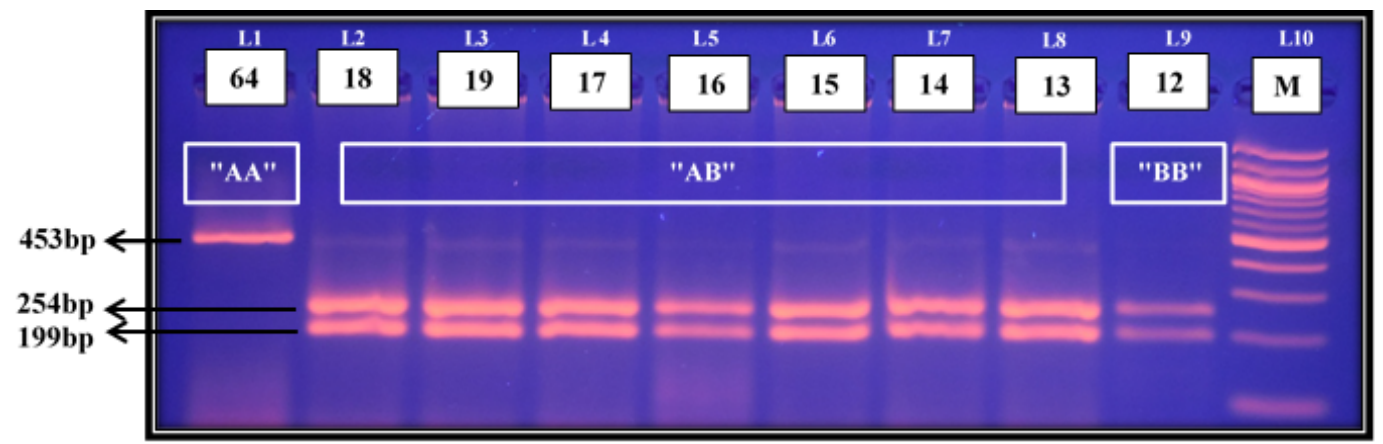

Figure 4. Gel electrophoresis for restricted fragments of $\kappa-\mathrm{CN}$ gene digested with $A c u \mathrm{I}$ enzyme which represented only by sample code 64, Lane: 1 (L1). While the remaining lanes from L2 to L9 represent the restricted fragments of $\kappa-\mathrm{CN}$ gene digested with HpyCH4IV enzyme; L2 to L8 represent "AB" genotype (453, 254 and 199 bp) while L9 represents "BB" genotype (254 and 199 bp). M Lane: 100 bp DNA ladder. Animals codes 12 to 19 . Run conditions: agarose gel $3 \%$ for $120 \mathrm{~min}$ at $100 \mathrm{v}$ and $40 \mathrm{~mA}$

The results of the present study revealed a genetic polymorphism of $\kappa-\mathrm{CN}$ gene by using PCR-RFLP technique with $A c u$ I enzyme in agreement with El Nahas et al. (2013) and El Nahas and Abou Mossallam (2015) but only by detecting two genotypes "AA" and "AB" with the absence of "BB" genotype. While, El Nahas et al. (2013) and El Nahas and Abou Mossallam (2015) identified three genotypes "AA","BB" and "AB".

PCR-RFLP results using AcuI enzyme disagreed with the majority of reviewed PCR-RFLP studies conducted by HindIII , Hinfl or MaeII restriction enzymes which concluded that, all Egyptian buffaloes were monomorphic and genotyped as homozygous "BB" animals as reported by Othman (2005); El-Rafey and Darwish (2008); and Abdel Dayem et al. (2009). Similar results were also noticed, in Pakistani buffalo (Riaz et al., 2008; Ghafoor et al., 2015), in Indian buffalo (Gangaraj et al., 2008; Shende et al., 2009; Nair et al., 2011; George et al., 2018), in Brazilian buffalo (Otaviano et al., 2005), in Chinese water buffalo (Ren et al., 2011), in Iraqi buffalo (Jaayid et al., 2013), in Anatolian water buffalo breed (Cinar et al., 2016), in swamp and river Indonesian buffaloes (Margawati et al., 2016), in Cuban buffalo (Marrero et al., 2016), and in Iranian buffalo (Abbasi et al., 2009).

The results of PCR-RFLP technique with $H p y C H 4 \mathrm{IV}$ enzyme revealed a genetic polymorphism of $\kappa$-CN gene with genotypes "BB" (254 and $199 \mathrm{bp}$ ) and "AB" (453, 254 and $199 \mathrm{bp}$ ). These results disagreed with Riaz (2013) who characterized Pakistani buffalo by using MaeII restriction enzyme (Isoschizomer for HpyCH4IV) as monomorphic animals with only "BB" genotypes (254 and $199 \mathrm{bp}$ ).

Coincidence with results of HpyCH4IV enzyme, Gouda et al. (2013) also found genetic polymorphism in Egyptian buffalo using PCR-RFLP with HindIII restriction enzyme after digesting of $379 \mathrm{bp}$ PCR product of $\kappa-\mathrm{CN}$ gene with "BB" and "AB" genotypes. Similar results were observed in Indian River buffalo bulls (Patel et al., 2007). On the other hand, Lin et al. (2013) detected three genotypes "AA", "BB" and "AB" in water buffalo breeds.

(2) RFLP Analysis for PCR Products of $\beta$-LG Gene (247 bp)

The amplified PCR products of $\beta$-LG gene (247 bp) digested by HaellI restriction enzyme yielded only one pattern of restricted product (148 and $99 \mathrm{bp}$ ) for homozygotes "AA" as depicted in Figure 5, which indicated that all tested animals were monomorphic for $\beta$-LG gene. These findings signified that PCR-RFLP assay with HaeIII enzyme for $\beta$-LG gene may be failed to discover any evidence of polymorphism in Egyptian buffalo comparing to Cattle or all studied animals actually possess only one allele. 


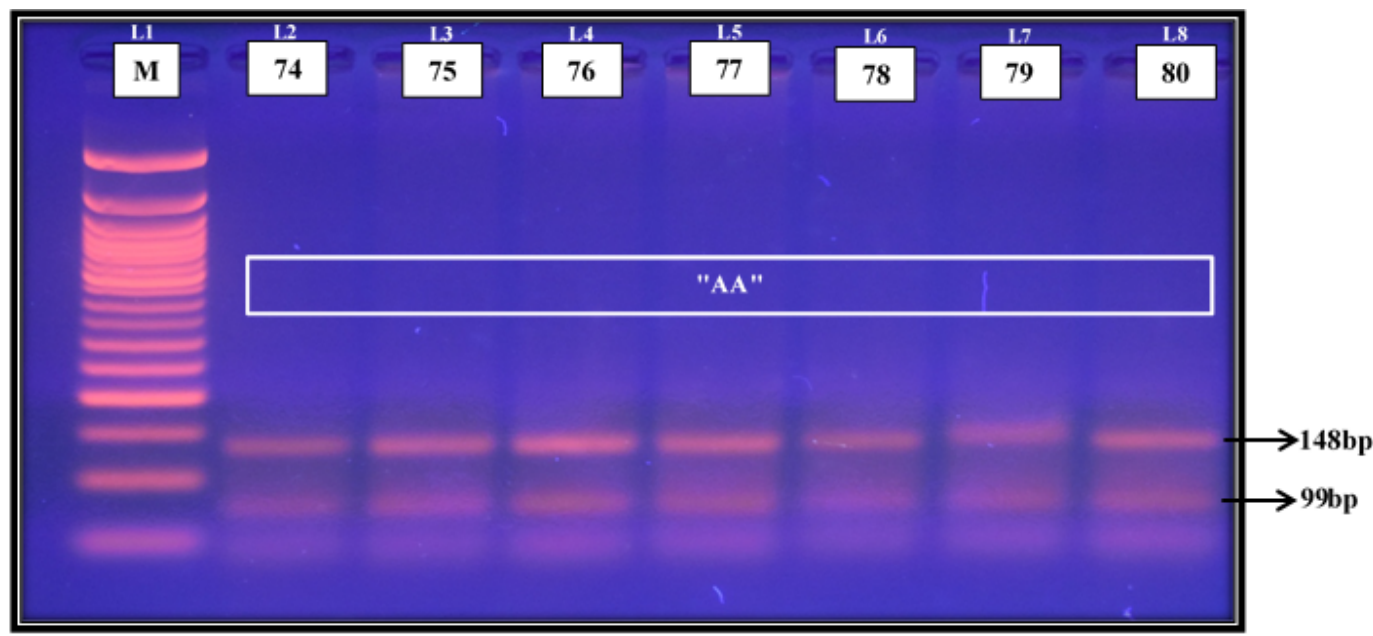

Figure 5. Gel electrophoresis for restricted fragments of $\beta$-LG digested with HaeIII enzyme. M Lane: $50 \mathrm{bp}$ DNA ladder. Animals codes 74 to 80. All lanes represent "AA" genotype (148 and 99 bp). Run conditions: agarose gel $3 \%$ for $120 \mathrm{~min}$ at $100 \mathrm{v}$ and $40 \mathrm{~mA}$

Some authors reported the same monomorphic pattern of $\beta$-LG gene by using PCR-RFLP with HaeIII enzyme through digesting different amplicon sizes such as, Ren et al. (2011) who used PCR-RFLP technique with HaeIII enzyme for digesting $252 \mathrm{bp}$ of amplified PCR product and detected only one type of restricted pattern with three fragments of 108, 74 and $70 \mathrm{bp}$, assigned as homozygous "BB" genotype for all Chinese water buffalo. Likewise, Nualchuen et al. (2012) detected only one restricted fragments pattern yielded five fragments of 113 , 99, 89, 73 and $24 \mathrm{bp}$ of digested 398bp of amplified PCR product (spanning over 104 bases of exon IV and 294 bases of intron IV) for all Swamp and Murrah buffaloes.

On contrary to these results, Gouda et al. (2011) applied PCR-RFLP technique with HaeIII enzyme to digest of a $262 \mathrm{bp}$ PCR product of exon IV and intron IV, which resulted in polymorphic locus of $\beta$-LG gene in Egyptian buffaloes, with the presence of three types of restriction patterns: three fragments of 109,79 and 74 bp as "BB" genotype, four fragments of $154,109,79$ and $74 \mathrm{bp}$ as "AB" genotype and the last pattern, a rare genotype, "BC" that had three fragments of 154,79 and $74 \mathrm{bp}$.

In coincidence with these observations, in India, Nair et al. (2011) detected only one type of restricted patterns for all their examined Nagpuri buffaloes representing the heterozygous genotype "AB" through applying PCR-RFLP technique of a 247 bp PCR product with HaeIII enzyme and consequently the presence of two genetic variants "A" and "B" in their population, i.e., Nagpuri buffaloes possess genetic polymorphism at $\beta$-LG gene locus but with only single restricted fragments pattern.

Results were disagreed with some other investigations performed on different buffalo breeds which revealed the polymorphism at $\beta$-LG gene locus with two genetic variants "A" and "B" by applying PCR-RFLP with HaeIII enzyme of 247 bp PCR product as Patel et al. (2007); Karimi et al. (2009); Cinar et al. (2016).

(3) Determination of Compacted Genotypes

The DNA patterns arising from the digestion of 453bp PCR of $\kappa-\mathrm{CN}$ gene with $A c u \mathrm{I}$ and $H p y C H 4 \mathrm{IV}$ enzymes were combined to create new synthesized genotype (Compacted genotype) for each animal possess two restriction patterns of the restricted enzymes as reviewed by Barroso et al. (1998). Identification of compacted genotypes required the combined information of the two enzymes. Cumulative restriction pattern through restriction analysis of $\kappa-\mathrm{CN}$ gene indicated different genotypes using two restriction enzymes are presented in (Table 5). These compacted genotypes were created through mixing of the following restricted patterns of DNA: The heterozygous fragments pattern of $A c u \mathrm{I}$ and $H p y C H 4 \mathrm{IV}$ enzymes were "C" (453, 339 and $114 \mathrm{bp})$ and " $\mathrm{F}$ " (453, 254 and $199 \mathrm{bp}$ ), respectively. The monomorphic undigested fragment pattern (453 bp) was " $A$ " variant for $A c u$ I enzyme and "D" variant for HpyCH4IV enzyme, while the monomorphic digested fragment pattern was "B" (339 and 114 bp) and "E" (254 and 199 bp) for AcuI and HpyCH4IV enzymes, respectively.

As clarified in Table 5, three detected combinations were detected according to results of PCR-RFLP analysis as "AF", "CE" and "CF" genotypes. 
Table 5. Cumulative restriction pattern analysis of $\kappa-\mathrm{CN}$ gene

\begin{tabular}{|c|c|c|c|c|c|c|}
\hline \multirow{3}{*}{$\begin{array}{l}\text { Compacted Genotypes } \\
\mathrm{AD}\end{array}$} & \multicolumn{6}{|c|}{ Cumulative restriction pattern analysis } \\
\hline & \multicolumn{3}{|c|}{ AcuI Enzyme } & \multicolumn{3}{|c|}{ HpyCH4IV Enzyme } \\
\hline & 453 & - & - & 453 & - & - \\
\hline $\mathrm{AE}$ & 453 & - & - & - & 254 & 199 \\
\hline $\mathrm{AF}^{*}$ & 453 & - & - & 453 & 254 & 199 \\
\hline $\mathrm{BD}$ & - & 339 & 114 & 453 & - & - \\
\hline $\mathrm{BE}$ & - & 339 & 114 & - & 254 & 199 \\
\hline $\mathrm{BF}$ & - & 339 & 114 & 453 & 254 & 199 \\
\hline $\mathrm{CD}$ & 453 & 339 & 114 & 453 & - & - \\
\hline $\mathrm{CE}^{*}$ & 453 & 339 & 114 & - & 254 & 199 \\
\hline $\mathrm{CF}^{*}$ & 453 & 339 & 114 & 453 & 254 & 199 \\
\hline
\end{tabular}

Note. $(*)$ refers to genotypes detected in the present study in bp.

\subsection{Allelic and Genotypic Frequencies of Studied Genes}

\section{(1) Allelic and Genotypic Frequencies of $\kappa-\mathrm{CN}$ Gene}

Two distinct alleles " $\mathrm{A}$ " and "B" were detected in all examined animals either through digesting with $A c u \mathrm{I}$ or HpyCH4IV enzymes. According to results of gel electrophoresis for restricted fragments of AcuI enzyme, "A" allele was the predominance allele within all farm locations with allelic frequencies ranged from 0.52 to 0.62 , while "B" allele had a lower allelic frequencies with values ranged from 0.38 to 0.48 as illustrated in Table 6 . In this study, the overall values of allelic frequencies of "A" and "B" were 0.58 and 0.42 , respectively. The same results were mentioned by El Nahas et al. (2013) with 0.57 and 0.43 , respectively.

$A c u I$ results showed that, two genotypes were observed "AA" and "AB" genotypes, with the absence of homozygous "BB" animals. 70 to $95 \%$ of the examined animals were heterozygous with average value of $83 \%$ and genotyped as "AB", while the observed genotypic frequencies of homozygous "AA" ranged from 5 to $30 \%$ with average value of $17 \%$ as mentioned in Table 7. On contrary, El Nahas et al. (2013) noticed rare frequency of homozygous "BB" (0.06), but also reported the predominance of heterozygous "AB" with frequency of 0.65 .

According to results of PCR-RFLP with HpyCH4IV enzyme, "A" and "B" alleles had an equal allelic frequency (0.5) in most farms. The lowest value of "A" allele (0.42) recorded in C.F. farm as given in Table 6. Heterozygous genotype "AB" was the most frequent genotype among all locations with overall value close to one, while the monomorphic genotype "BB" was noticed in extremely low frequency $(0.04)$ and "AA" genotype was absent as shown in Table 7. These findings disagreed with Gouda et al. (2013) who reported that 75\% of Egyptian buffaloes had the monomorphic "BB" genotype and only $25 \%$ of individuals was heterozygotes "AB" with the predominance of "B" allele (0.875) according to PCR-RFLP results of HindIII restriction enzyme. Likewise, Patel et al. (2007) concluded that homozygous genotype "BB" $(0.968)$ was the most frequent genotype comparing to "AB" genotype (0.032) in Indian River buffalo bulls and the frequency of "B" allele was $(0.984)$.

On contrary to these findings, most studies conducted to identify the allelic and genotypic frequencies of $\kappa-\mathrm{CN}$ gene of Egyptian buffaloes using PCR-RFLP method with HindIII and Hinfl enzymes recorded only the existence of the monomorphic "BB" genotype with allelic frequency of "B" allele equal to one (Othman, 2005; El-Rafey \& Darwish, 2008; Abdel Dayem et al., 2009).

With the same gene primers, Riaz et al. (2008) and Abbasi et al. (2009) reported that (453 bp) amplified PCR product of $\kappa-\mathrm{CN}$ gene yielded only fragments pattern of homozygous and genotyped as monomorphic "BB" (1.00) with Hinfl, HaeIII and MaeII restriction enzymes in Nili-Ravi buffaloes of Pakistan and Hinfl restriction enzyme in buffaloes of Khouzestan province of Iran, respectively.

Similar results of monomorphic "BB" were obtained in Nili-Ravi buffaloes using PCR-RFLP analysis with of (443 bp) fragment of PCR product of $\kappa-\mathrm{CN}$ with HindIII restriction enzyme as reported by Ghafoor et al. (2015). Also, the restriction digestion analysis of $(350 \mathrm{bp})$ PCR product of $\kappa-\mathrm{CN}$ with Hinfl enzyme referred to the presence of only one genotype of "BB" in Nagpuri buffaloes of India as mentioned by Nair et al. (2011).

The cumulative genotypic pattern results using two restricted enzymes ( $A c u \mathrm{I}$ and $H p y C H 4 \mathrm{IV}$ enzymes) observed from the digestion of $\kappa-\mathrm{CN}$ gene fragment clarified that heterozygous combinations "CF" were the most obvious through all studied buffalo populations and ranged from 0.70 to 0.91 (Table 7), which referred that all studied populations of Egyptian buffaloes were polymorphic animals. On contrary, Riaz (2013) applied the cumulative 
genotypic pattern using three enzymes Hinfl, HaeII and MaeII and noticed the existence of only "BB" genotype.

Table 6. Allelic frequencies of $\kappa-\mathrm{CN}$ and $\beta-\mathrm{LG}$ gene in Egyptian buffaloes

\begin{tabular}{|c|c|c|c|c|c|c|c|c|}
\hline \multirow{2}{*}{ Gene } & \multirow{2}{*}{ Locus } & \multirow{2}{*}{ Alleles } & \multicolumn{5}{|c|}{ Allelic frequencies of studied Populations } & \multirow{2}{*}{ Overall } \\
\hline & & & C.F. & K.S. & Sh.F. & I.S. & S.S. & \\
\hline$\beta$-LG & HaeIII & A & 1.00 & 1.00 & 1.00 & 1.00 & 1.00 & 1.00 \\
\hline \multirow{8}{*}{$\kappa-\mathrm{CN}$} & \multirow{2}{*}{$A c u \mathrm{I}$} & A & 0.52 & 0.62 & 0.60 & 0.55 & 0.61 & 0.58 \\
\hline & & $\mathrm{B}$ & 0.48 & 0.38 & 0.40 & 0.46 & 0.39 & 0.42 \\
\hline & \multirow{2}{*}{ НруСH4IV } & A & $0.42^{-}$ & 0.48 & 0.50 & 0.50 & 0.50 & 0.48 \\
\hline & & $\mathrm{B}$ & 0.58 & 0.52 & 0.50 & 0.50 & 0.50 & 0.53 \\
\hline & \multirow{4}{*}{ Created Alleles } & A & 0.25 & 0.12 & 0.15 & 0.46 & 0.11 & 0.20 \\
\hline & & $\mathrm{C}$ & 0.25 & 0.38 & 0.35 & 0.04 & 0.39 & 0.28 \\
\hline & & $\mathrm{E}$ & 0.07 & 0.02 & 0.00 & 0.00 & 0.00 & 0.02 \\
\hline & & $\mathrm{F}$ & 0.43 & 0.48 & 0.50 & 0.50 & 0.50 & 0.48 \\
\hline
\end{tabular}

Note. ( $\beta$-LG) beta Lactoglobulin gene; $(\kappa-\mathrm{CN})$ kappa casein gene; (C.F.) Farm of Agriculture College of Cairo University; (K.S.) Kafr El-Sheikh Agricultural Research Station, (Sh.F.) Farm of Agriculture College of Shebeen El-Kom, Menoufia University; (I.S.) Ismailia Agricultural Research Station; (S.S.) Sids Research Station, Beni Suef Governorate.

Table 7. Observed numbers of genotypes and genotypic frequencies of $\kappa-\mathrm{CN}$ and $\beta$-LG gene in Egyptian buffaloes

\begin{tabular}{|c|c|c|c|c|c|c|c|c|c|c|c|c|c|}
\hline \multirow{3}{*}{ Gene } & \multirow{3}{*}{ Locus } & \multirow{3}{*}{$\begin{array}{l}\text { Observed } \\
\text { Genotypes }\end{array}$} & \multicolumn{10}{|c|}{ Observed numbers and Genotypic frequencies of studied Populations } & \multirow{3}{*}{ Overall } \\
\hline & & & \multicolumn{2}{|c|}{ C.F. } & \multicolumn{2}{|c|}{ K.S. } & \multicolumn{2}{|c|}{ Sh.F. } & \multicolumn{2}{|c|}{ I.S. } & \multicolumn{2}{|c|}{ S.S. } & \\
\hline & & & Obs. & F. & Obs. & F. & Obs. & F. & Obs. & F. & Obs. & F. & \\
\hline$\beta-\mathrm{LG}$ & HaeIII & AA & 1.00 & 1.00 & 1.00 & 1.00 & 1.00 & 1.00 & 1.00 & 1.00 & 1.00 & 1.00 & 1.00 \\
\hline \multirow{7}{*}{$\kappa-\mathrm{CN}$} & \multirow{2}{*}{$A c u \mathrm{I}$} & $\mathrm{AA}$ & 1 & 0.05 & 6 & 0.21 & 2 & 0.20 & 1 & 0.09 & 3 & 0.30 & 0.17 \\
\hline & & $\mathrm{AB}$ & 19 & 0.95 & 23 & 0.79 & 8 & 0.80 & 10 & 0.91 & 7 & 0.70 & 0.83 \\
\hline & \multirow{2}{*}{ HруCH4IV } & $\mathrm{BB}$ & 3 & 0.17 & 1 & 0.03 & 0 & 0.00 & 0 & 0.00 & 0 & 0.00 & 0.04 \\
\hline & & $\mathrm{AB}$ & 15 & 0.83 & 28 & 0.97 & 10 & 1.00 & 11 & 1.00 & 10 & 1.00 & 0.96 \\
\hline & \multirow{3}{*}{$\begin{array}{l}\text { Compacted } \\
\text { Genotypes }\end{array}$} & $\mathrm{AF}$ & 1 & 0.05 & 6 & 0.21 & 2 & 0.20 & 1 & 0.09 & 3 & 0.30 & 0.17 \\
\hline & & $\mathrm{CE}$ & 3 & 0.17 & 1 & 0.03 & 0 & 0.00 & 0 & 0.00 & 0 & 0.00 & 0.04 \\
\hline & & $\mathrm{CF}$ & 14 & 0.78 & 22 & 0.76 & 8 & 0.80 & 10 & 0.91 & 7 & 0.70 & 0.79 \\
\hline
\end{tabular}

Note. (Obs.) Observed Number, (F.) Frequency; ( $\beta$-LG) beta Lactoglobulin gene; ( $\kappa-\mathrm{CN})$ kappa casein gene; (C.F.) Farm of Agriculture College of Cairo University; (K.S.) Kafr El-Sheikh Agricultural Research Station, (Sh.F.) Farm of Agriculture College of Shebeen El-Kom, Menoufia University; (I.S.) Ismailia Agricultural Research Station; (S.S.) Sids Research Station, Beni Suef Governorate.

(2) Allelic and Genotypic Frequencies of $\beta$-LG Gene

In the current study, all studied buffaloes were monomorphic for $\beta$-LG gene and genotyped as homozygous "AA" (100\%) with "A" allelic frequency of 1.00 as given in Tables (6) and (7). Similar monomorphic results but with different genotype were noticed by Ren et al. (2011) and Nualchuen et al. (2012) using different amplicon sizes with genotypic frequencies equal to one.

These results disagreed with Gouda et al. (2011) who found three alleles "A", "B" and "C" in Egyptian buffaloes through digesting of 262 bp PCR product of exon IV and intron IV using HaeIII enzyme. "B" allele had the largest frequency of 0.917 , while " $\mathrm{A}$ " allele had a lower value $(0.055)$ followed by " $\mathrm{C}$ " allele with $(0.028)$. Homozygous genotype "BB" was the predominant genotype $(0.833)$ with rarely observed heterozygous genotypes "AB" $(0.111)$ and "BC" $(0.055)$ and the absence of homozygous "AA" genotype. Also, the dominance of "BB" genotype (0.66) was reported by Karimi et al. (2009). On contrary, Patel et al. (2007) and Cinar et al. (2016) noticed the predominance of heterozygous "AB" with genotypic frequencies of 0.586 and 0.698 , respectively. 
As well as, some other investigations conducted on different buffalo breeds found two alleles " $\mathrm{A}$ " and "B" for $\beta$-LG gene, some of them recorded the predominance of " $\mathrm{B}$ " allele with values of 0.595 and 0.8125 as reported by Patel et al. (2007) and Karimi et al. (2009), respectively. From the other hand, Riaz (2013) and Cinar et al. (2016) found that "A" allele was the most frequent allele in Nili-Ravi and Anatolian water buffaloes with values of 0.64 and 0.603 respectively. Whereas, Nair et al. (2011) detected only the heterozygous genotype "AB" $(100 \%)$ and the allelic frequency of 0.5 for each allele; " $A$ " and "B" of $\beta-L G$ in all Nagpuri buffaloes of India.

\subsection{Heterozygosity and Inbreeding Coefficient $\left(F_{I S}\right)$ of $\kappa$-CN Gene}

Results of Table 8 showed that all observed heterozygosity estimates $\left(\mathrm{H}_{0}\right)$ of $\kappa-\mathrm{CN}$ gene per loci within populations are significantly higher than those of biased $\left(\mathrm{H}_{\mathrm{e}}\right)$ and non-biased $\left(\mathrm{H}_{\text {n.b. }}\right)$ expected heterozygosity which is considered as an indication of heterozygosity excess in all populations, i.e., higher degree of genetic variability between individuals within these populations. Estimates of $\mathrm{H}_{\mathrm{o}}$ were strongly high and ranged from 0.77 to 0.95 , with average value of $84.2 \%$ for $A c u$ I locus and from 0.85 to 1.00 , with average value of $96.4 \%$ for HpyCH4IV locus, while $\mathrm{H}_{\text {n.b. }}$ values ranged from 0.48 to 0.52 and from 0.50 to 0.53 , with average value of $50.4 \%$ and $51.8 \%$ for $A c u \mathrm{I}$ and $H p y C H 4 \mathrm{IV}$ loci, respectively.

These findings were also confirmed by the obtained negative values of inbreeding within the populations $\left(\mathrm{F}_{\mathrm{IS}}\right)$ which were ranged from -0.60 to -0.90 and from -0.73 to -1.00 , for $A c u$ I and $H p y C H 4 \mathrm{IV}$ loci, respectively as mentioned in Table 9. These findings showed that the majority of studied individuals were heterozygous, i.e., these populations depended on outbreeding or mating with migrants. In disagreement with these results, Ghafoor et al. (2015) noticed that there were no heterozygotes observed within Nili-ravi buffaloes due to all animals had homozygous genotype "BB".

Several authors estimated expected and observed heterozygosity to identify the genetic variability for $\kappa-\mathrm{CN}$ gene in different cattle breeds and reported that the observed heterozygotes of $\kappa-\mathrm{CN}$ gene were significantly differ from the expected one, i.e., some cattle breeds had a heterozygote excess as reported by Sulimova et al. (2007) who found that most of Russian cattle breeds had a heterozygote excess with $\mathrm{H}_{\mathrm{o}}$ ranged from (0.0.27 to 0.60$)$ and $\mathrm{H}_{\mathrm{e}}$ ranged from $(0.26$ to 0.50$)$, as well as, Zepeda-Batista et al. (2015) found that the Mexican Jersey cattle showed differences $(\mathrm{P}<0.05)$ between observed $\left(\mathrm{H}_{\mathrm{o}}=0.50\right)$ and expected $\left(\mathrm{H}_{\mathrm{e}}=0.45\right)$ heterozygosity, These results indicated a high allelic diversity for $\kappa-\mathrm{CN}$ that could be included in breeding programs in the population studied, aimed to improve the milk quality traits of economic importance.

Table 8. Estimates of heterozygosity per locus within populations

\begin{tabular}{|c|c|c|c|c|c|c|c|c|}
\hline \multirow{2}{*}{ Gene } & \multirow{2}{*}{ Locus } & \multirow{2}{*}{ Heterozygosity } & \multicolumn{5}{|c|}{ Population } & \multirow{2}{*}{ Overall Mean (\%) } \\
\hline & & & C.F. & K.S. & Sh.F. & I.S. & S.S. & \\
\hline \multirow{3}{*}{$\beta-\mathrm{LG}$} & \multirow{3}{*}{ HaeIII } & $\mathrm{H}_{\mathrm{e}}$ & 0.00 & 0.00 & 0.00 & 0.00 & 0.00 & - \\
\hline & & $\mathrm{H}_{\text {n.b. }}$ & 0.00 & 0.00 & 0.00 & 0.00 & 0.00 & - \\
\hline & & $\mathrm{H}_{\mathrm{o}}$ & 0.00 & 0.00 & 0.00 & 0.00 & 0.00 & - \\
\hline \multirow{9}{*}{$\kappa-\mathrm{CN}$} & \multirow{3}{*}{$A c u \mathrm{I}$} & $\mathrm{H}_{\mathrm{e}}$ & 0.50 & 0.47 & 0.48 & 0.50 & 0.48 & 48.6 \\
\hline & & $\mathrm{H}_{\text {n.b. }}$ & 0.51 & 0.48 & 0.51 & 0.52 & 0.50 & 50.4 \\
\hline & & $\mathrm{H}_{\mathrm{o}}$ & 0.95 & 0.77 & 0.80 & 0.91 & 0.78 & 84.2 \\
\hline & \multirow{3}{*}{ НруСH4IV } & $\mathrm{H}_{\mathrm{e}}$ & 0.49 & 0.50 & 0.50 & 0.50 & 0.50 & 49.8 \\
\hline & & $\mathrm{H}_{\text {n.b. }}$ & 0.50 & 0.51 & 0.53 & 0.52 & 0.53 & 51.8 \\
\hline & & $\mathrm{H}_{\mathrm{o}}$ & 0.85 & 0.97 & 1.00 & 1.00 & 1.00 & 96.4 \\
\hline & \multirow{3}{*}{$\begin{array}{l}\text { Compacted } \\
\text { Genotypes }\end{array}$} & $\mathrm{H}_{\mathrm{e}}$ & 0.69 & 0.61 & 0.61 & 0.54 & 0.59 & 60.8 \\
\hline & & $H_{\text {n.b. }}$ & 0.71 & 0.62 & 0.64 & 0.57 & 0.62 & 63.2 \\
\hline & & $\mathrm{H}_{\mathrm{o}}$ & 1.00 & 1.00 & 1.00 & 1.00 & 1.00 & 100 \\
\hline
\end{tabular}

Note. $(\beta-\mathrm{LG})$ beta Lactoglobulin gene; $(\kappa-\mathrm{CN})$ kappa casein gene; $\left(\mathrm{H}_{\mathrm{e}}\right)$ biased expected heterozygosity; $\left(\mathrm{H}_{\mathrm{n} . \mathrm{b}}\right)$ non-biased expected heterozygosity; $\left(\mathrm{H}_{\mathrm{O}}\right)$ observed heterozygosity; (C.F.) Farm of Agriculture College of Cairo University; (K.S.) Kafr El-Sheikh Agricultural Research Station, (Sh.F.) Farm of Agriculture College of Shebeen El-Kom, Menoufia University; (I.S.) Ismailia Agricultural Research Station; (S.S.) Sids Research Station, Beni Suef Governorate. 
Table 9. Estimates of inbreeding coefficient $\left(\mathrm{F}_{\mathrm{IS}}\right)$ per locus within populations

\begin{tabular}{lllllll}
\hline \multirow{2}{*}{ Gene } & \multirow{2}{*}{ Locus } & \multicolumn{5}{c}{ Population } \\
\cline { 3 - 6 } & C.F. & K.S. & Sh.F. & I.S. & S.S. \\
\hline$\beta$-LG & AcuI & - & - & - & - & - \\
\multirow{3}{*}{$\kappa-C N$} & HpyCH4IV & -0.90 & -0.61 & -0.64 & -0.82 & -0.60 \\
& Overall & -0.66 & -0.93 & -1.00 & -1.00 & -1.00 \\
& & -0.72 & -0.74 & -0.88 & -0.75 \\
\hline
\end{tabular}

Note. ( $\beta$-LG) beta Lactoglobulin gene; ( $\kappa-\mathrm{CN})$ kappa casein gene; (NA) not available; (C.F.) Farm of Agriculture College of Cairo University; (K.S.) Kafr El-Sheikh Agricultural Research Station, (Sh.F.) Farm of Agriculture College of Shebeen El-Kom, Menoufia University; (I.S.) Ismailia Agricultural Research Station; (S.S.) Sids Research Station, Beni Suef Governorate.

Similar results noticed by Akyüz et al. (2013) who mentioned that $H_{o}$ value of (26) was higher than $H_{e}$ value of (24.8889) in Brown Swiss. In addition to Ghafoor et al. (2015) who inferred that there was a little of genetic variability due to the lower value of $H_{o}$ with 0.09 and 0.04 , respectively compared to $H_{e}$ value of 0.33 and 0.076 , respectively in Achai and Sahiwal cattle of Pakistan.

On the other hand, some cattle breeds had a heterozygote deficit as reported by Sulimova et al. (2007) who found that one herd of Yaroslavl cattle breed that had $\mathrm{H}_{\mathrm{o}}$ value (0.43) lower than $\mathrm{H}_{\mathrm{e}}$ value (0.50). Similarly, Akyüz et al. (2013) demonstrated that there was a heterozygote deficit in Simmental and Holstein breeds due to the lower values of $H_{o}$ (18 and 37, respectively) compared to the corresponding $H_{e}$ values (20.3636 and 43.7826, respectively. As well as, Mohammadi et al. (2013) reported that the observed heterozygotes of $\kappa$-CN gene were extremely lower than the expected one in Iranian Holstein cattle with $H_{o}$ value of $(0.18)$ and $H_{e}$ value of $(0.31)$. Additionally, Miluchová et al. (2018) inferred that the Holstein cattle breed exhibit a high value of homozygosity with $\mathrm{H}_{\mathrm{o}}$ value of $(0.2762)$ and $\mathrm{H}_{\mathrm{e}}$ value of $(0.7222)$.

\subsection{Heterozygosity and Inbreeding Coefficient $\left(F_{I S}\right)$ of $\beta$-LG Gene}

According to monomorphic results of $\beta$-LG gene with homozygous "AA" genotype, estimation of heterozygosity for that gene would be equal to zero, indicating that there were no heterozygotes observed within these populations as illustrated in Table 8 and consequently, the value of inbreeding coefficient could not be estimated as showed in Table 9. Mohammadi et al. (2013) reported that the observed heterozygotes of $\beta$-LG gene were extremely lower than the expected one in Iranian Holstein cattle with $\mathrm{H}_{\mathrm{o}}$ value of $(0.28)$ and $\mathrm{H}_{\mathrm{e}}$ value of (0.49). However, Zepeda-Batista et al. (2015) found that the Mexican Jersey cattle showed differences $(\mathrm{P}<0.05)$ between observed $\left(\mathrm{H}_{\mathrm{o}}=0.50\right)$ and expected $\left(\mathrm{H}_{\mathrm{e}}=0.41\right)$ heterozygosity, i.e., these animals had a heterozygote excess.

\subsection{Genetic Diversity for Studied Genes}

The genetic distance estimates among Egyptian buffalo populations were mentioned in Table 10. The smallest genetic distance was noticed between Shebeen EL-Kom and Sids populations with a value of 0 which indicated that these two populations were genetically identical, In other words, there was minimal or no genetic diversity between these the two populations, whereas, the largest genetic distance was observed between Kafr EL-Sheikh and Ismailia populations with a value of 0.037 which indicated that these two populations were genetically distant. Ismailia was the most genetically different or distinct population from other studied populations with estimates ranged from 0.025 to 0.037 . These findings were supported by the phylogenetic tree of the studied populations as shown in Figure (6) which suggested that there was close relationship between the three populations of Kafr EL-Sheikh, Sids and Shebeen EL-Kom, while the population of Cairo had larger genetic distance with these former populations.

Using 12 microsatellite markers data, Merdan (2020) estimated the genetic distance among the exact Egyptian buffalo populations which had also been used in our research and in coincidence with our results and found that the population of Kafr El-Sheikh was most genetically distant than Ismailia population with a value of 0.373. In disagreement with these findings, the smallest genetic distance was detected between Ismailia and Sids populations with a value of 0.200 . Although, the results of using microsatellite markers were more accurate than using RFLP analysis data for genes polymorphism data, due to the unprecedented ability of microsatellite to detect and describe genetic differences between populations. In addition, RFLP analysis data were successful to differentiate between populations with acceptable results. 
Table 10. Genetic distance among Egyptian buffalo populations according to Nei (1972)

\begin{tabular}{lllll}
\hline Distance matrix & Kafr EL-Sheikh & Shebeen EL-Kom & Ismailia & Sids \\
\hline Cairo & 0.009 & 0.014 & 0.025 & 0.016 \\
Kafr EL-Sheikh & & 0.003 & 0.037 & 0.002 \\
Shebeen EL-Kom & & & 0.029 & 0.000 \\
Ismailia & & & 0.034 \\
\hline
\end{tabular}
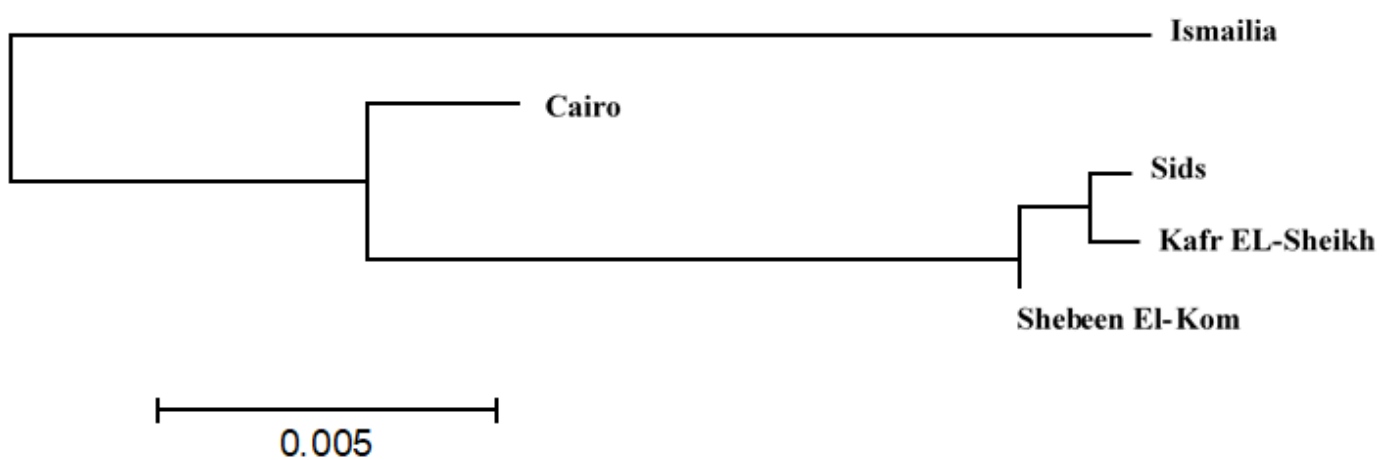

Figure 6. A rooted genetic dendrogram constructed by Nei's genetic distances among five studied populations of Egyptian buffaloes

\section{Conclusions}

From the previous results it can be concluded that:

(1) Polymorphism at the level of $\kappa-\mathrm{CN}$ gene had been successfully detected through using PCR-RFLP technique with both $A c u \mathrm{I}$ and $H p y C H 4 \mathrm{IV}$ enzymes, however, we recommended using $A c u \mathrm{I}$ enzyme which was more capable for differentiating between homozygous $(17 \%)$ and heterozygous $(83 \%)$ individuals than HpyCH4IV enzyme which defined only $4 \%$ of homozygous individuals and the remaining was heterozygous (96\%) individuals.

(2) Egyptian buffaloes were found to be polymorphic animals for $\kappa-\mathrm{CN}$ gene with two distinct alleles " $\mathrm{A}$ " and "B", while they were monomorphic animals for $\beta-L G$ gene with only " $\mathrm{A}$ " allele.

(3) Existence of heterozygosity excess in all studied populations refers to higher degree of genetic variability between individuals within these populations.

\section{References}

Abbasi, B., Fayazi, J., Nasiri, M. B., Roshanfekr, H. A., Mirzadeh, K., \& Sadr, A. S. (2009). Analysis of kappa casein gene polymorphism by PCR-RFLP in buffalo population in Khouzestan Province. Research Journal of Biological Sciences, 4(10), 1073-1075.

Abdel Dayem, A. M. H., Mahmoud, K. G. M., Nawito, M. F., Ayoub, M. M., \& Darwish, S. F. (2009). Genotyping of kappa-casein gene in Egyptian buffalo bulls. Livestock Science, 122, 286-289. https://doi.org/10.1016/j.livsci.2008.09.010

Akyüz, B., Arslan, K., Bayram, D., \& Işcan, K. M. (2013). Allelic frequency of kappa-casein, growth hormone and prolactin gene in Holstein, Brown Swiss and Simmental cattle breeds in Turkey. Kafkas Universitesi Veteriner Fakultesi Dergisi, 19(3), 439-444. http://doi.org/10.9775/kvfd.2012.7985

Awad, A., El Araby, I. E., El-Bayomi, K. M., \& Zaglool, A. W. (2016). Association of polymorphisms in kappa casein gene with milk traits in Holstein Friesian cattle. Japanese Journal of Veterinary Research, 64(2), S39-S43.

Barroso, A., Dunner, S., \& Canon, J. (1998). Detection of Bovine Kappa-Casein Variants A, B, C, and E by Means of Polymerase Chain Reaction-Single Strand Conformation Polymorphism (PCR-SSCP). Journal of Animal Science, 76(6), 1535-1538. https://doi.org/10.2527/1998.7661535x

Borghese, A., \& Mazzi, M. (2005). Buffalo Population and Strategies in the world. Buffalo Production and Research, 67, 1-39. 
Cinar, M. U., Akyuz, B., Arslan, K., \& Ilgar, E. G. (2016). Genotyping of the kappa-casein and beta-lactoglobulin genes in Anatolian water buffalo by PCR-RFLP. International Journal of Dairy Technology, 69(2), 308-311. https://doi.org/10.1111/1471-0307.12257

Cockrill, W. R. (1981). The Water Buffalo: A Review. British Veterinary Journal, 137(1), 8-16. https://doi.org/ 10.1016/S0007-1935(17)31782-7

Eggen, A. (2012). The development and application of genomic selection as a new breeding paradigm. Animal Frontiers, 2(1), 10-15. https://doi.org/10.2527/af.2011-0027

El Nahas, S. M., \& Abou Mossallam, A. A. (2015). AcuI identifies water buffalo CSN3 genotypes by RFLP analysis. Journal of Genetics, 94(1), 94-96. https://doi.org/10.1007/s12041-014-0427-3

El Nahas, S. M., Bibars, M. A., \& Taha, D. A. (2013). Genetic characterization of Egyptian buffalo CSN3 gene. Journal of Genetic Engineering and Biotechnology, 11(2), 123-127. https://doi.org/10.1016/j.jgeb.2013. 08.003

El-Rafey, G. A., \& Darwish, S. F. (2008). A PCR-RFLP assay to detect genetic variants of kappa-casein gene in cattle and buffalo. Arab Journal of Biotechnology, 11(1),11-18.

FAO (Food and Agriculture Organization of the United Nations). (2019). Live Animals data. Rome, Italy.

Gangaraj, D. R., Shetty, S., Govindaiah, M. G., Nagaraja, C. S., Byregowda, S. M., \& Jayashankar, M. R. (2008). Molecular characterization of kappa-casein gene in buffaloes. Science Asia, 34, 435-439. https://doi.org/ 10.2306/scienceasia1513-1874.2008.34.435

George, J., Kuralkar, S., Ali, S. S., Bankar, P., Deshmukh, S., \& Kuralkar, P. (2018). Study of polymorphism of kappa casein gene in Marathwadi and Purnathadi buffalo. Ruminant Science, 7(2), 213-215.

Ghafoor, A., Riaz, M. N., Zahur, A. B., Abbas, N., Yousaf, M., Shah, A., ... Suleman, M. (2015). K-CN gene polymorphism in Nili-ravi buffalo, Achai and Sahiwal cattle of Pakistan. International Journal of Dairy Technology, 68(1), 105-110. https://doi.org/10.1111/1471-0307.12146

Golijow, C. D., Giovambattista, G., Rípoli, M. V., Dulout, F. N., \& Lojo, M. M. (1999). Genetic variability and population structure in locirelated to milk production traits in nativeArgentine Creole and commercial ArgentineHolstein cattle. Braz. J. Genet., 22, 395-398. https://doi.org/10.1590/S1415-47571999000300018

Gouda, E. M., Galal, M. K., \& Abdelaziz, S. A. (2013). Genetic variants and allele frequencies of kappa casein in Egyptian cattle and buffalo using PCR-RFLP. Journal of Agricultural Science, 5(2), $197-203$. https://doi.org/10.5539/jas.v5n2p197

Gouda, E. M., Galal, M. K., Wasfy, M. A., \& Abdelaziz, S. A. (2011). Phenotypes, Genotypes and Allele Frequencies of B-lactoglobulin in Egyptian Cattle and Buffalo. Journal of Agricultural Science, 3(4), 203-210. https://doi.org/10.5539/jas.v3n4p203

Goudet, J. (2002). FSTAT version 2.9.3.2, a program to estimate and test gene diversities and fixation indices. Retrieved from http://www2.unil.ch/popgen/softwares/fstat.htm

Groeneveld, L. F., Lenstra, J. A., Eding, H., Toro, M. A., Scherf, B., Pilling, D., ... Globaldiv, C. (2010). Genetic diversity in farm animals-A review. Animal Genetics, 41(1), 1-26. https://doi.org/10.1111/ j.1365-2052.2010.02038.x

Hamad, M. N. E., El-Moghazy, M. M., \& Abdel-Aziz, M. E. (2014). Phenotypic correlations among Egyptian buffalo milk production and its major chemical constituents. Journal of Food and Dairy Sciences, 5(10),741-749. https://doi.org/10.21608/jfds.2014.53216

Hassanein, M. K., Abolmaaty, S. M., Khalil, A. A., Taqi, M. O., Essa, Y. H., \& Shawki, H. H. (2013). Geographical Distribution and Developmental Pattern of Buffalo in Egypt. World Rural Observations, 5(4), 14-19.

Hussain, D. A., \& Twayej, M. H. (2016). Genetic structure analysis of kappa-casein gene/HindIII and its relationship with some productive traits in Iraqi cows population (comparative study). World Journal of Pharmaceutical Research, 5(4), 30-38.

Jaayid, T. A., Yousief, M. Y., Zaqeer, B. F., \& Owaid, J. M. (2013). Genetic Polymorphism of Kappa Casein $(\kappa-\mathrm{CN})$ in Iraqi Buffalo Using Polymerase Chain Reaction-Restriction Fragment Length Polymorphism. Journal of Agricultural Science and Technology, A3(10A), 835-841. 
Kalinowski, S. T. (2005). Do polymorphic loci require large sample sizes to estimate genetic distances? Heredity, 94(1), 33-36. https://doi.org/10.1038/sj.hdy.6800548

Karimi, K., Nasiri, M. T., Fayyazi, J., Mirzadeh, K. H., \& Roushanfekr, H. (2009). Allele and genotype frequencies of $\beta$-lactoglobulin gene in Iranian Najdi cattle and buffalo populations using PCR-RFLP. African Journal of Biotechnology, 8(15), 3654-3657.

Kemenes, P. A., Reginato, L. C. A., Rosa, A. J. M., Parker, I. U., Razook, G. A., Figueiredo, L. A., ... Coutinho, L. L. (1999). k-casein, b-lactoglobulin nagrowth hormone allele frequencies and genetic distances in Nelore, Gyr, guzerá, Caracu,Charolais, Canchin and Santa Gertrudis cattle. Genet. Mol. Biol., 22, 539-541. https://doi.org/10.1590/S1415-47571999000400012

Lara, M. A. C., Gama, L. T., Bufarah, G., Sereno, J. R. B., Celegato, E. M. L., \& De Abreu, U. P. (2002). Genetic polymorphisms at the k-casein locus in Pantaneiro cattle. Archivos de Zootecnia, 51(194), 99-105.

Lin, B., Ren, D., Yang, B., Li, L., Yan, T., Long, H., \& Zeng, Q. (2013). Compare of Phenotypic Variation with the Polymorphism of One Coagulation Related Gene Locus in Buffalo Kappa-Casein. Buffalo Bulletin, 32(2), 805-810. https://doi.org/10.4081/ijas.2013.e85

Margawati, E. T., Volkandari, S. D., \& Talib, C. (2016). Genotyping of Kappa-Casein Gene of Buffalo in Indonesian. Conference Paper. https://doi.org/10.14334/Proc.Intsem.LPVT-2016-p.37-44

Marrero, N. M., de Mascena, L. A., de Macedo, J. L., Valdés, A. M., Filho, M. A. G., \& Reinosa, O. U. (2016). Genotyping of the kappa-casein and leptin genes in Cuban water buffalo by PCR-RFLP. Revista de Salud Animal, 38(2), 71-78.

Medrano, J. F., \& Aguilar-Cordova, E. (1990a). Genotyping of bovine kappa-casein loci following DNA sequence amplification. Nature Biotechnology, 8(2), 144-146. https://doi.org/10.1038/nbt0290-144

Medrano, J. F., \& Aguilar-Cordova, E. (1990b). Polymerase chain reaction amplification of bovine $\beta$-lactoglobulin genomic sequences and identification of genetic variants by RFLP analysis. Animal Biotechnology, 1(1), 73-77. https://doi.org/10.1080/10495399009525730

Merdan, S. M. (2020). Using microsatellite markers to assess the genetic diversity in Egyptian buffaloes (PhD thesis, Faculty of Agriculture, Suez Canal University, Egypt).

Miluchová, M., Gábor, M., Candrák, J., Trakovická, A., \& Candráková, K. (2018). Association of HindIII-polymorphism in kappa-casein gene with milk, fat and protein yield in Holstein Cattle. Acta Biochimica Polonica, 65(3), 403-407. https://doi.org/10.18388/abp.2017_2313

Miluchová, M., Trakovická, A., \& Gábor, M. (2012). Analysis of Beta-Lactoglobuline Gene (LGB) Polymorphism in Different Breeds of Bulls by High Resolution Melting. Scientific Papers Animal Science and Biotechnologies, 45(1), 193-197.

Mohammadi, Y., Aslaminejad, A. A., Nassiry, M. R., \& Esmailizadeh Koshkoieh, A. (2013). Allelic polymorphism of K-casein, $\beta$-Lactoglobulin and leptin genes and their association with milk production traits in Iranian Holstein cattle. Journal of Cell and Molecular Research, 5(2), 75-80.

Nair, A. K., Sirothia, A. R., Patel, R. K., Soni, K. J., Singh, K. M., Sirothia, K. A., \& Gawande, T. R. (2011). Characterization of $\kappa$-casein and $\beta$-Lactoglobulin gene in Nagpuri buffaloes (Bubalus bubalis). Wayamba Journal of Animal Science, 578, 153-157.

Naqvi, A. N. (2007). Application of molecular genetic technologies in livestock production: Potentials for developing countries. Advances in Biological Research, 1(3-4), 72-84

Nei, M. (1972). Genetic Distance between Populations. American Naturalist, 106(949), 283-292. https://doi.org/ $10.1086 / 282771$

Nei, M. (2001). Genetic Distance. Encyclopedia of Genetics, 828-832. https://doi.org/10.1006/rwgn.2001.0532

Nei, M., \& Takezaki, N. (1983). Estimation of genetic distances and phylogenetic trees from DNA analysis. Proceedings of the $5^{\text {th }}$ World Congress on Genetics Applied to Livestock Production, 21, 405-412.

Nualchuen, W., Srisakwattana, K., Chethasing, S., Tasripoo, K., Usawang, S., Hengtrakulsin, R., \& Kamonpatana, M. (2012). RFLP Analysis of Beta-Lactoglobulin Gene in Swamp and Murrah Buffaloes Using a Single Restriction Enzyme. Iranian Journal of Applied Animal Science, 2(3), 301-303. 
Otaviano, A., Tonhati, H., Sena, J. A. D., \& Cerón Muñoz, M. F. (2005). Kappa-casein gene study with molecular markers in female buffaloes (Bubalus bubalis). Genetics and Molecular Biology, 28(2), 237-241. https://doi.org/10.1590/S1415-47572005000200010

Othman, E. O. (2005). The identification of kappa-casein genotyping in Egyptian river buffalo using PCR-RFLP. Arab Journal of Biotechnology, 8(2), 265-274.

Othman, E. O., Zayed, F. A., El Gawead, A. A., \& El-Rahman, M. R. A. (2011). Genetic polymorphism of three genes associated with milk trait in Egyptian buffalo. Journal of Genetic Engineering and Biotechnology, 9(2), 97-102. https://doi.org/10.1016/j.jgeb.2011.09.002

Patel, R., Chauhan, J., Singh, K., \& Soni, K. (2007). Genotyping and allelic frequencies of $\kappa-C N$ and $\beta$-LG in Indian river buffalo bulls. Buffalo Bull, 26(3), 63-66.

Perera, B. M. (2011). Reproductive cycles of buffalo. Animal Reproduction Science, 124(3-4), 194-199. https://doi.org/10.1016/j.anireprosci.2010.08.022

Ren, D. X., Miao, S. Y., Chen, Y. L., Zou, C. X., Liang, X. W., \& Liu, J. X. (2011). Genotyping of the k-casein and $\beta$-lactoglobulin genes in Chinese Holstein, Jersey and water buffalo by PCR-RFLP. Journal of Genetics, 90(1), e1-e5. https://doi.org/10.1007/s12041-011-0048-z

Riaz, M. N. (2013). Genetic polymorphism of bovine growth hormone (somatotropin), kappa-casein and beta-lactoglobulin genes (Doctoral dissertation, Quaid-i-Azam University Islamabad, Pakistan).

Riaz, M. N., Malik, N. A., Nasreen, F., Sadaf, S., \& Qureshi, J. A. (2008). Molecular Marker Assisted Study of Kappa-Casein Gene in Nili-Ravi (Buffalo) Breed of Pakistan. Buffalo Bull, 27(3), 240-244.

Shende, T. C., Sawane, M. P., \& Pawar, V. D. (2009). Genotyping of Pandharpuri buffalo for k-casein using PCR-RFLP. Tamilnadu Journal of Veterinary and Animal Sciences, 5(5), 174-178.

Sulimova, G. E., Azari, M. A., Rostamzadeh, J., Abadi, M. M., \& Lazebny, O. E. (2007). א-casein gene (CSN3) allelic polymorphism in Russian cattle breeds and its information value as a genetic marker. Russian Journal of Genetics, 43(1), 73-79. https://doi.org/10.1134/S1022795407010115

Takezaki, N., Nei, M., \& Tamura, K. (2010). POPTREE2, software for constructing population trees from allele frequency data and computing other population statistics with Windows interface. Molecular Biology and Evolution, 27, 747-752. https://doi.org/10.1093/molbev/msp312

Yang, W., Kang, X., Yang, Q., Lin, Y., \& Fang, M. (2013). Review on the development of genotyping methods for assessing farm animal diversity. Journal of Animal Science and Biotechnology, 4(1), 2. https://doi.org/ $10.1186 / 2049-1891-4-2$

Zepeda-Batista, J. L., Alarcón-Zúñiga, B., Ruíz-Flores, A., Núñez-Domínguez, R., \& Ramírez-Valverde, R. (2015). Polymorphism of three milk protein genes in Mexican Jersey cattle. Electronic Journal of Biotechnology, 18(1), 1-4. https://doi.org/10.1016/j.ejbt.2014.10.002

\section{Copyrights}

Copyright for this article is retained by the author(s), with first publication rights granted to the journal.

This is an open-access article distributed under the terms and conditions of the Creative Commons Attribution license (http://creativecommons.org/licenses/by/4.0/). 